\title{
The Failure of Project Eyeball: A Case of Product Overpricing or Market Overcrowding?
}

\author{
Marc Edge \\ Nanyang Technological University, Singapore
}

\begin{abstract}
The closure in mid-2001 by Singapore Press Holdings (SPH) of its experimental tabloid newspaper, Project Eyeball, after less than 1 year of publication, was popularly attributed to a pair of market factors: its 80-cent cover price and competition from a pair of free tabloids that entered the market hot on its heels. Although pricing and competition were doubtless important contributing factors to Project Eyeball's rapid demise, a pair of additional economic concepts emerges on closer examination of the newspaper's brief history and may provide additional clues to its failure. One is the principle of relative constancy, which held, until it was disproved in the 1980s, that the level of expenditures on media remained fairly constant as a percentage of the overall economy. The other is the influence on management practices of share prices of publicly traded newspaper companies, into which category SPH falls. Considering these factors in addition to price and competition helps to better explain the rapid demise of Project Eyeball.
\end{abstract}

Project Eyeball was announced in February 2000 by Singapore Press Holdings (SPH) as "Singapore's first integrated print and cyberspace news publication" for "the Net-savvy and opinionated young Singaporean” (Ong, 2000, p. 1). It was an experimental project, taking a "hybrid" form as both an upscale tabloid newspaper and a continually updated Web site, complete with not only text reports but also audio and video postings. Its Sunday edition would be an Internet-only offering. Ambitious projections foresaw circulation of 100,000 and profitability within 3 years (Chua, 2000). SPH gave away 120,000 copies of Project Eyeball daily for a week following its launch on August 12, 2000.

The experiment lasted for less than a year, with disastrous results. Less than halfway through its brief life, Project Eyeball was described as a "flop" by Asiaweek magazine, which reported, "Advertisers shun it, readers can't find it, and not even the SPH hierarchy likes it" (Mitton, 2001, p. 8). When SPH announced on June 27, 2001 that it was pulling the plug and folding the newspaper, a company spokesman admitted Project Eyeball had lost S \$13.3 million (U.S. \$7.3 million) while achieving a circulation of less than 20,000 (Rajeev, 2001). A postmortem consensus

Address correspondence to Marc Edge, School of Communication and Information, Nanyang Technological University, 31 Nanyang Link, Singapore 637718, Singapore. E-mail: mail@marcedge.com attributed the failure of Project Eyeball to a pair of market factors (“Media War and Pricing Hurt Eyeball," 2001):

1. Overpricing. The cover price of Project Eyeball had been set at 80 cents, compared with 60 cents for the thick Straits Times, the broadsheet flagship of market-dominant $\mathrm{SPH}$.

2. Increased competition. Shortly after the launch of Project Eyeball, Singapore witnessed an explosion in the number of newspapers published following a liberalization of government media regulation. As a result, government-owned broadcaster MediaCorp began publication in November 2000 of a giveaway tabloid titled Today, in partnership with local transit companies. In response, SPH started up yet another new daily, a commuter tabloid giveaway cryptically called Streats. ${ }^{1}$

These explanations for the demise of Project Eyeball suggest some theoretical implications. Prevailing economic wisdom posits that demand for newspapers by readers is relatively price inelastic, and that higher cover prices should not affect sales significantly (Lacy \& Simon, 1993, pp. 30-31). This seems to be contradicted by the Singapore experience. Competition theory is also relevant to this case study, as colorful tabloid newspapers have proven a successful challenge to market-leading broadsheets in contradiction of the natural monopoly theory of newspapers that has traditionally been ad- 
vanced to explain newspaper markets. Although Singapore may indeed prove fertile ground for a tabloid competitor to the Straits Times, the fact that three of them began publishing in such a short period may have proved too much, too soon. This article chronicles the brief history of Project Eyeball and examines economic and regulatory factors for clues to its rapid demise. The preceding explanations and any others that present themselves are then examined for plausibility.

\section{Background}

Singapore is an island city-state approaching 4 million in population located near the equator in Southeast Asia, at the tip of the Malay Peninsula, from which it is separated by the narrow Strait of Johor. Enjoying virtually no natural resources-even its domestic water supply has to be imported by pipeline from Malaysia-Singapore has nonetheless built itself through trade into one of the leading "tiger economies" of Asia since gaining its independence from Britain in 1959. A recent specialization in the high-tech industry brought an enviable standard of living by the end of the past century, but the recent worldwide economic downturn has seen a slowing of the rapid economic growth Singapore experienced in the 1980s and 1990s. Much of Singapore's success can be attributed to centralized management of its economy under the leadership of founding Prime Minister Lee Kuan Yew. Now retired from that position but still involved in government as Senior Minister, Lee built Singapore into an economic powerhouse at the same time as he earned an international reputation for strict press restrictions, including licensing of newspapers (Seow, 1998). A series of government-mandated press mergers in the early 1980s resulted in a nationwide newspaper monopoly for SPH, publisher of the venerable Straits Times, which was founded in 1845 and currently boasts a daily circulation of more than 350,000.

Project Eyeball took life in 2000 as the 11th newspaper published by SPH, which is a diversified conglomerate with interests in book publishing and real estate. SPH publishes newspapers in all four official languages of multicultural Singapore-English, Chinese (Mandarin), Malay, and Tamil Indian. Its English-language publications, in addition to the Straits Times, include the broadsheet Business Times, and The New Paper, an afternoon tabloid that began publication in 1988 and initiated a tradition of innovative titles for startup dailies at $\mathrm{SPH}$, which was continued by Project Eyeball and Streats. ${ }^{2}$

The granting of a newspaper license to MediaCorp and of broadcasting licences to SPH in June 2000 was designed to introduce "controlled competition" to Singapore's media (Ang, 2002, p. 246). In announcing the moves, Minister for Information and the Arts Lee Yock Suan said they were necessary to allow SPH and MediaCorp to take advantage of the synergies provided by the worldwide trend toward media convergence while preserving the government's long-held policy of keeping the reporting of Singapore affairs under local control (Ong, 2000). Within hours of deregulation, MediaCorp announced it had formed a consortium to publish Today with Singapore Mass Rapid Transit (SMRT), which operates the island's subway system (30\%), the local bus company (15\%), and phone company Singapore Telecom, also known as Singtel (10\%). The latter had, through its Yellow Pages subsidiary, published a weekly all-advertising "shopper" for more than 2 years before recently folding it. MediaCorp, which held the balance of $45 \%$ of shares in the new publishing company, said it projected circulation of its new tabloid, which would contain "bite-sized" news stories for busy commuters, to hit 200,000 in its first year, with an annual revenue target of S \$75 million within 5 years (Ong, 2000). MediaCorp Chief Executive Officer Lim Hup Seng said the aim was not to capture readers with typical tabloid fare of sex and crime, however. "We're not going to be sleazy," said Lim. "We don't have the stomach for it" (Ong, 2000, p. 1). Reported the Business Times:

\footnotetext{
By partnering the transport companies, MediaCorp hopes to overcome the problem of distribution that had crippled past competitors to The Straits Times including The Singapore Monitor and Singapore Herald. Mr Lim denied that the consortium is copying the business plan of Swedish group, Modern Times but dropping it as a partner. Modern Times was earlier engaged in talks with SMRT to launch a metro newspaper. (Ong, 2000, p. 1)
}

A commuter tabloid for Singapore had been rumored for some time following the success of giveaway publications in Europe and North America. An explosion of such newspapers had been seen in 20 countries since their successful 1995 introduction in Stockholm by Swedish company Modern Times Group (MTG), which was later renamed Metro International. According to Bakker, MTG alone boasted a circulation of 8.5 million among 21 titles in 15 countries by 2002, when it entered the newspaper market in a 16th country, Hong Kong (Bakker, 2002). In 1999, MTG was reported to be in negotiation with Singaporean transit companies to duplicate there its formula that had proven so popular across Europe and North America ("All the News That Fits," 1999) According to the Business Times, however, the talks broke down because of MTG's failure, as a foreign firm, to secure a newspaper license (Ong, 2000).

To head the competing Project Eyeball team, SPH appointed 35-year-old Straits Times Deputy News Editor Bertha 
Henson, a former political reporter. She promised the new print and Internet publication would be "provocative and controversial" in its quest for an eventual readership of 600,000 (Teh, 2000, p. 1). Provocative and controversial were two qualities for which the press in Singapore had not been known since the government-forced consolidation of ownership in the early 1980s. "I think it is about time for some of these views to surface," said Henson of simmering antigovernment sentiments. "Because if we don't, then they will simply go underground and we'll simply lose credibility as a publishing company" (Teh, 2000, p. 1). Henson promised Project Eyeball would seek readers' views through its online version, with forums, chat rooms, and interaction with newsmakers and journalists. "We don't want a bunch of indifferent readers passively accepting our interpretation of news" (Chua, 2000, p. 1). In short, Henson promised a reversal of the existing press paradigm in Singapore, where the Straits Times was widely seen as the mouthpiece of the ruling People's Action Party (PAP), which had held power in a de facto one-party political system throughout the four decades since independence. "It won't be a lecturer-student relationship," insisted Henson of Project Eyeball. "It will be like we're sitting on barstool and drinking a vodka with you” (Olynec, 2000). Some PAP politicians expressed skepticism. "There is an unfortunate trend in the competitive media to play up the bad cases," said Lim Boon Heng, minister without portfolio. "If you want to do investigative reporting, there must be something that is wrong which has not been attended to. I think there are not many issues in Singapore that fall under that category" (Webb, 2000, p. 9).

By the end of 2000, Singaporeans had more newspapers to choose from than ever, and competition among them was fierce. Headlines in Project Eyeball and The New Paper atop coverage of the annual Miss Singapore Universe beauty pageant-such as "They Couldn't Even Speak Good English," "Beauty Without Brains," and "Survival of the Dumbest"-drew official government criticism. Information and the Arts Minister Lee called the tabloid coverage "ungracious and unfair to the contestants" and cautioned the rival media companies against biased reporting "in their drive to outdo each other" ("Telling It Like It Is," 2001, p. H15). Lurid and racy news photographs in some of the newly competitive dailies also drew criticism in the conservative city-state.

Soon bad news came in the form of SPH financial figures. Startup costs for both Project Eyeball and Streats, along with millions of dollars spent to begin broadcasting at English- and Chinese-language television and radio stations, had cut sharply into SPH's previously high profit margin. Contributing to a more than \$19-million decline in profits during the first 6 months of the fiscal year had been $\$ 4.8$ million spent on the launch of Project Eyeball (“SPH's Net Dropped," 2001). Worse yet, a long-overdue economic downturn worldwide caused the company to warn that its financial performance for the balance of the fiscal year would be "weak" ("SPH's Net Dropped," 2001). SPH managers had put a brave face on the regulatory changes that had robbed it of its monopoly the previous year. By stimulating competition, the changes would bring more prosperity for all, the company reasoned. "This is not a zero sum game," argued SPH's Executive Vice President for Marketing, Tham Khai Wor. "The pie is going to get bigger. Even if we lose 3-4 per cent, it will be a bigger pie" (Ong, 2000, p. 1). SPH's share of the S $\$ 1.4$ billion advertising market in Singapore was then 53\%, compared with 32\% for MediaCorp, but one rationale advanced for media liberalization was that the total advertising market would grow with more publications. Proponents of this view pointed to the fact that Singapore's advertisement expenditures amounted to less than $0.9 \%$ of gross domestic product (GDP), compared with $1.8 \%$ to $2.0 \%$ in countries such as the United States and Japan (Teh, 2000). Nevertheless, news that SPH would lose its newspaper monopoly triggered "nervous" selling of its shares, according to the Business Times, to a low of S $\$ 25.70$ (Teh, 2000). Ten months later, news of SPH's profit decline in the first half of its 2000-2001 fiscal year dropped its shares 70 cents to a 52-week low of $\$ 20.10$ (Sivanithy, 2001). By the time of the announcement in June 2001 that SPH would close Project Eyeball, the price of its shares had fallen to $S \$ 18.40$, its lowest point since February 1999 ("SPH to Close Project Eyeball Thursday," 2001). News of the closure, however, sent the share price up a full dollar within a day ("S'pore Stocks Creep Higher at Close," 2001).

\section{Additional Theoretical Considerations}

The preceding review suggests two additional economic factors worth taking into account in explaining the failure of Project Eyeball.

1. The principle of relative constancy (PRC). First enunciated in 1972 by McCombs, the PRC stated that media expenditures by consumers and advertisers will remain fairly fixed over time as a percentage of the economy. More recent research, however, has found that this does not hold true in an era of new technology (Lacy \& Ghee-Young, 1997).

2. Stock market influence. Bagdikian (1980) claimed that widespread public ownership of newspaper chains has led to competition in a third market-the stock market-in addition to the markets for information and advertising, in which newspapers have traditionally been acknowledged to compete (p. 64). Recent research in the United States suggests that newspaper company stock 
prices can indeed play a considerable role in management decision making, often rendering long-range strategy subservient to the short-term urgencies of share price (Cranberg, Bezanson, \& Soloski, 2001).

The remainder of the article discusses the experience of Project Eyeball in relation to the enunciated four theoretical factors.

\section{Discussion}

Each of the four factors discussed assists to some extent in explaining why and how Project Eyeball was launched and suffered such a rapid demise. The experience of Project Eyeball, in turn, provides a valuable case study to assist in assessing the validity of each of these theoretical considerations, several of which have been controversial. Each will be considered in the light of Project Eyeball, with the assistance of published data.

\section{Pricing}

According to Blankenburg (1995), the inelastic nature of demand for newspapers means that when readers find no acceptable substitute, they endure aggressive pricing. However, when acceptable substitutes are available, readers have proven quite sensitive to price adjustments. History has shown the effects of pricing on demand for newspapers from the days of the penny press, when drastic reductions in cover prices caused demand to skyrocket. In the modern era, the real-world effects of newspaper pricing were seen clearly in mid-1990s England, where Rupert Murdoch reduced the cover price of his Times of London from 45 pence to 20 pence in 1993 . The resulting 10-year price war saw the Times more than double its circulation of 360,000 for a time (Doyle, 2002, p. 131). The million-selling Daily Telegraph was forced to match Murdoch's price cut, but by the end of 1996 circulation of the Times had climbed to a record 861,931 (Snoddy, 1996). A decade later, the Times had given back some of its gains, however, with its circulation receding to 631,653 whereas the Telegraph's stood at 916,208 (Preston, 2003). The price war finally ended when the Times boosted its price back to normal levels in September 2003, pricing its editions at 50 pence on weekdays compared to the Telegraph's 55 pence (Glover, 2003). The long-running battle of attrition provided ample evidence for many that price was indeed an important variable in newspaper demand, however. "The newspaper battle in Britain surprised industry observers who predicted when it began that quality newspapers were not price-sensitive like cans of beans in a supermarket," noted one observer.
"The Times' soaring circulation proved them wrong" (Drohan, 1998, p. B1).

As Doyle (2003) noted, "The main determinant of elasticity is the availability of substitutes or of products that are perceived as substitutes" (p. 129). When SPH first published Project Eyeball and priced it at 80 cents, there were not yet any free tabloids published in Singapore. That situation promised to quickly change as SPH lost its newspaper monopoly in the city-state and MediaCorp announced it would begin publication of Today as a free tabloid in competition with Project Eyeball. That prompted SPH to trump its new competition with a giveaway tabloid of its own. The following timeline of events in 2000 compiled by Lim (2003) conveniently illustrates the sequence of events:

June 5: MediaCorp unveils Today, a free commuter tabloid.

June 7: SPH announces September launch date for Streats.

August 12:Singapore sees Project Eyeball for first time.

September 2: Streats hits the streets.

November 10: Today begins circulation.

The sudden advent of newspaper competition in Singapore on June 5 , both as announced by the government and as made into a reality by MediaCorp with its unveiling of Today, put SPH in the unfamiliar position of responding to changes in the market that were not of its own doing. It chose to respond decisively to MediaCorp's entry, but in trumping its new competition, SPH effectively sacrificed its previously conceived Project Eyeball, which at that point was doomed by its 80-cent cover price. "A monopolist can get away with charging very high prices whereas the existence of rival suppliers in the market in the market will encourage firms to compete" (Doyle, 2003, p. 127). The importance of time as a variable in newspaper competition is also seen clearly in the case of deregulation in Singapore. According to Sylvie and Witherspoon (2002) time and change have been underappreciated factors in understanding competition in the newspaper business: "Publications that do not change also do not adequately monitor their markets. ... Simple economics dictates that newspapers must meet market challenges or die" (p. 7). SPH failed to anticipate changes to the newspaper market in Singapore when it conceived Project Eyeball, and as a result it withered from infancy.

Lacy and Simon (1993) suggested that quality is a more useful factor to consider in understanding newspaper demand than price (pp. 30-31) Martin's (1998) resource-based model adds to the demand equation such 
standard economic concepts as utility, opportunity cost, and consumer surplus. A newspaper's "price" includes the cost of opportunities foregone while reading it, according to Martin, and providing utility in excess of the price paid by the reader results in a consumer surplus to the buyer. "Increasing quality increases the utility consumers receive, thereby decreasing the opportunity cost of consuming a given firm's content. Media firms that create quality content reduce consumer elasticity of demand, and should enjoy a competitive advantage" (Martin, 1998). The unique quality provided by Project Eyeball during its brief life included two aspects: a "tech-savvy" writing style aimed at capturing a younger readership attractive to advertisers for its disposable income, and an irreverent attitude toward politics designed to engage readers who had long been offered only bland commentary. Neither was apparently sufficient to raise utility above the 80-cent publication price and thus attract enough readers to survive. The fact that most of Project Eyeball's editorial content was available to read at no cost on the Internet may also have played a part in the failure to stimulate demand for this product.

According to former Project Eyeball editor Bertha Henson, journalists involved with the fledgling daily resisted pricing the new newspaper so steeply. "Frankly, from the start, I thought it was too high," said Henson. "In fact, I would say that the editorial [department] fought against it because it was too much, too high" (B. Henson, personal communication, December 22, 2000). SPH Marketing Director Tham Kai Wor said the decision to price Project Eyeball at 80 cents was "a deliberate experiment on our part to try to raise newspaper prices in Singapore” (K. Tham, personal communication, February 25, 2003). The experiment obviously failed, but according to Tham it was deemed a necessary gamble by SPH.

We took a chance. We just had to do it, because there was also competition. We wanted to find a new market. It goes back to the 1980s, when we started to design The New Paper. There was one category which The New Paper was supposed to target-those English literates who are not reading any newspaper at all. We failed. ... Eyeball had many, many factors working against it. The main one is this group is not newspaper readers. (K. Tham, personal communication, February 25, 2003)

SPH wrote a new chapter on newspaper pricing in Singapore in early 2004, when it raised the cover prices of all its titles, including a 33\% hike for the Straits Times, from 60 cents to 80 cents (Sai, 2004). The steep and unexpected price rise brought criticism from the Consumers Association of Singapore, but SPH cited rising costs of production and the fact that cover prices of its newspapers had not been raised since 1995 ("Case Takes Issue," 2004).

\section{Competition}

Control of newspaper publishing in Singapore is a legacy of the British colonial era, when publications were required to be licensed under the classic authoritarian model of the press. Controls were tightened further after Singapore achieved independence from Britain in 1959, as simmering ethnic tensions became ignited by press coverage in several notable instances. A brief merger with Malaysia ended in dissolution in the mid-1960s, after which circulation of newspapers from that country was prohibited (Ang, 2002, p. 244). A series of government-mandated press mergers in the early 1980s led to the establishment in 1984 of SPH as a newspaper monopoly publishing morning and afternoon editions of dailies in all four official languages of Singapore. That situation prevailed until deregulation in 2000, when limited competition was reintroduced.

The creation of SPH can be seen as codification by government fiat of the natural monopoly theory of newspapers. This theory explained the gradual disappearance of competing daily newspapers in many cities around the world due to the "circulation spiral," under which the larger of two competing dailies would come to be preferred by advertisers for its greater reach. The trailing daily would gradually lose advertisers and, as a result, readers, until it became unprofitable and was forced to close. The solution to the problem of dwindling newspaper competition in the United States and some other countries became the joint operating agreement, under which two or more dailies share expenses and split profits. However, by the 1980 s a new paradigm of product differentiation came to be preferred to the natural monopoly theory of newspapers, as morning tabloids emerged as viable second dailies in many cities that had been left as one-newspaper towns by the closure of second-place broadsheets. By dint of appealing to a younger readership demographic, these colorful tabloids often became profitable for the volume of advertising they attracted for consumer goods. Attracting a younger demographic has always been a problem for newspapers, but it has become increasingly pronounced in an era of new technology (Brody \& Picard, 1997, p. 134).

Perhaps as a result of the demonstrated success of morning tabloids in attracting a younger readership in other parts of the world, SPH introduced The New Paper as a tabloid in 1988 in an attempt to attract a younger readership. The attempt was largely a failure, perhaps in part due to the curious decision to make The New Paper an afternoon daily. In any event, according to SPH Marketing Director Tham Kai Wor, “The gain was very, very small” (K. Tham, personal communication, February 25, 2003). The problem of attracting younger readers to newspapers has been well documented in other countries, with "public journalism" movement of the 1990s largely aimed at re- 
ducing the "disconnect" that citizens increasingly feel from civic life. This disconnect is perhaps even more pronounced in Singapore due to cultural peculiarities in the city-state. Censorship and political controls instituted in an attempt to increase economic performance and stabilize ethnic relations have resulted in a lowered level of political interest, particularly among young people (Banerjee \& Yeo, 2003, p. 281). A survey of 432 Singaporeans aged 15 to 29 taken by SPH in late 2000 showed a marked indifference to politics, with 9 of 10 saying they would never consider entering political life. This political apathy, according to a published analysis, extended to the point where young Singaporeans were even described as "contemptuous" of politics ("Youths Shun Politics," 2000).

The launch of Project Eyeball as a morning tabloid followed the more successful model of morning publication, but it was quickly emulated by MediaCorp with Today, which benefitted from the added attraction of free distribution. SPH countered with a similar morning giveaway in Streats, and the field was suddenly crowded. The approach taken by Project Eyeball in differentiating its product from this competition was in its content and mode of address. It promised in its initial edition that it would poke fun at Singapore's "strait-laced ways Christmas carol-style" and dig up the kind of stories that were not traditionally covered by the press in Singapore:

Reporters won't pen their prose from any ivory tower. They will crawl through the trenches at ground zero and surf the back alleys of the Net to deliver news you need to know. ... It will question. It will push you to think. It will give you a voice, even if it's not popular or politically correct. Most of all, it'll stick to what matters to you-the Internet-savvy young professional crowd. (Henson, 2000, p. 1)

Project Eyeball did indeed cover the offbeat, including Singapore's only sex change clinic, and its writing style was more informal than what Singaporeans had been used to reading. It insouciance persisted up until its final issue, in which it summed up its own demise as owing to the mistakes of "hitching ourselves onto the dotcom bandwagon" and "looking too much like a technology/Internet only newspaper." The bottom line, however, was the bottom line, as the newspaper itself admitted in its own front-page obituary. "But at the end of day, money talks. And we're not bringing in the moolah. But that's the way the world works" (Henson, 2001, p. 1). This irreverent attitude indeed "endeared itself to the young and Internet-savvy," according to an online obituary, which also reiterated the fundamental conundrum that spelled the newspaper's demise. "The ordinary Singaporean had to choose between paying 80 cents for Project Eyeball and getting the other newspapers free. I guess it wasn't a difficult decision" ("Project Eyeball Says Goodbye," 2001). Other cyberactive Singaporeans, however, were more cyni- cal and questioned whether Project Eyeball's irreverent questioning of authority had hastened its demise. "Is the closing down of Project Eyeball merely because of business reasons?" asked the short-lived group Singapore Media Watch, in a letter to the Web site Singaporeans for Democracy. "Could another reason be that it has overstepped the boundaries of politics in Singapore? Project Eyeball has been reporting a lot of articles on the opposition.... It has comprehensive reports of Workers Party handover as well as NSP's [National Solidarity Party] too" (Singapore Media Watch, 2001).

However, whatever competitive advantage the editors of Project Eyeball tried to gain, SPH management provided even more competition to its own offspring by providing yet another free choice for Singapore newspaper readers in Streats. This practically ensured the failure of Project Eyeball by dooming it from its steep cover price in face of the free competition. Although Streats was a more viable competitor for Today than Project Eyeball, and both enjoyed major economies of scale under SPH, enduring the inevitable startup losses of two new dailies was obviously more of a drain on the bottom line than management was prepared to allow to continue. After Project Eyeball folded, Streats more than held its own against Today, capturing about $13 \%$ of Singapore newspaper readership in its first year, compared with about $11 \%$ for Today (and only $1 \%$ for Project Eyeball). In 2002, the positions of the dueling giveaways reversed, with Today being read by $16.3 \%$ of Singaporeans, whereas Streats was read by only $10.3 \%$ (Loo, 2002). The loosening of regulations restricting competition in the Singapore newspaper market undoubtedly altered the playing field on which Project Eyeball competed. From enjoying a monopoly in newspaper publishing, SPH was suddenly in unfamiliar territory with competition from a new morning tabloid. The rapid demise of Project Eyeball can perhaps be thus seen as a kind of false start to competition.

\section{Relative Constancy}

The PRC (also known as the relative constancy hypothesis) has proven one of the more controversial mass communication theories over the past three decades, and has been criticized for its lack of grounding in economic theory. McCombs (1972) first examined data from 1929 to 1968 in concluding that the level of spending on media purchases by advertisers and consumers over that period had remained relatively constant as a percentage of gross national product (GNP), despite technological advances and variations in competition. Although the amount of advertising on television had increased markedly during the latter decades of his study, McCombs found that when adjusted for inflation, population growth, and increases in personal income, media expenditures as a whole had re- 
mained fairly constant as a percentage of GNP over the period, and had even declined from 3.46\% in 1929 to 3.04\% in 1968 (p. 24). This led to media economics being seen as a kind of "zero sum" game, with a decline in newspaper industry fortunes explained by an increase in advertising expenditures on television.

Subsequent research, however, found spending on media buying by advertisers to be not as fixed as first assumed by the PRC. Then with the advent of cable television and VCR technology in the 1980s, consumer spending on media was also found to rise in relative terms. As advertising expenditures are the focus of this section of the article, findings on that aspect of media buying are dealt with here. Research found that only about half of all television advertising revenue was "stolen" from other media, and that an increase in the number of radio stations also increased total advertising revenue (Lacy \& Noh, 1997, pp. 9-10). The resulting contradiction of the PRC in advertising expenditures perhaps became instead inspiration for media executives hoping to increase these revenues by exploiting advances in technology and competitive niches.

Thus, when SPH Marketing Director Tham Kai Wor stated on launching Project Eyeball, even in the face of increased competition from Today, that "this is not a zero sum game," and that "the pie is going to get bigger," he was relying, at least implicitly, on the disproving of the PRC. The increased media competition in Singapore seen at the turn of the millennium therefore provides an opportunity for further testing of the PRC. Data on advertising expenditures across media are easily available, as is that on GDP, and breaks down as shown in Table 1.

The verdict on whether increased competition in Singapore media has served to increase the size of the advertising revenue pie there over the long run will have to be reserved until several more years of data have been collected. However, given the slowdown in both the global and local economy, these increases could indicate that advertising revenue may well rise with increased competition. However, although this may serve as an explanation for the genesis of Project Eyeball, along with the host of other new publications that sprang up in Singapore in 2000 , it does not help to account for its closure, as more competition would seem to be preferred to less under this finding. For more clues we turn to our fourth and final area of theoretical consideration.

\section{Share Prices}

Ownership of newspaper companies by firms that are publicly traded on stock exchanges has been seen in other countries as a possible factor of significance in management decision making. The impact of financial markets on media management practices was first brought to the attention of many by Bagdikian, who identified it in the late 1970s as a factor that had been overlooked in understanding the impact of increased concentration of press ownership. He identified stock markets as a "third market" whose forces newspaper managers must account for, in addition to their acknowledged markets for readers and advertising.

The impact of trading newspaper corporate stock on the stock market has meant that news companies must constantly expand in size and rate of profits in order to maintain their position on stock exchanges.... Instead of the single master so celebrated in the rhetoric of the industrythe reader-there are in fact three masters. (Bagdikian, 1980, p. 64)

According to Underwood (1993), increased corporate ownership of dailies resulted in two trends during the 1970s and 1980s: professional management of newspapers, often by executives with little or no background in journalism; and an increasingly bottom-line, market-driven orientation. He argued that both trends were largely the result of stock market influences. "Wall Street, as publishers have learned, can be insatiable in the demand for earnings growth and unmerciful in hammering a stock if earnings drop" (p. 41). One recent study in the United States found such a marked effect on newspaper management of publicly traded share ownership that it urged the enactment of federal regulations to reverse the trend, despite First Amendment guarantees in that country against government interference in the operations of the press (Cranberg et al., 2001, pp. 147-148).

Table I. Advertising Revenues in Singapore, 1997-2002

\begin{tabular}{|c|c|c|c|c|c|}
\hline Year & $S P H(\$ ' m)$ & Today $(\$ ' m)$ & All Media & GDP $(\$ ' b)$ & $\%$ of GDP \\
\hline 1997 & 647.4 & & $1,275.3$ & 149.5 & .85 \\
\hline 1998 & 574.8 & & $1,186.5$ & 145.9 & .81 \\
\hline 1999 & 609.5 & & $1,219.9$ & 143.5 & .85 \\
\hline 2000 & 750.6 & 3.0 & $1,504.2$ & 160.9 & .93 \\
\hline 2001 & 643.2 & 36.7 & $1,541.0$ & 154.6 & 1.00 \\
\hline 2002 & 629.0 & 62.6 & $1,685.9$ & 155.7 & 1.08 \\
\hline
\end{tabular}

Note. From AC Nielsen, SPH, Singapore Dept. of Statistics. Used with permission from AC Nielsen. 
Although SPH shares trade on the local Singapore stock exchange and not on Wall Street, the principle is the same-share prices can be increased with short-term strategies that may not be in the firm's best long-term interest. Thus, pressure from shareholders could theoretically influence management decision making. The effect would become even more direct when executives of the newspaper company are themselves shareholders, or can take advantage of stock options. A review of share prices reveals that the trend line for SPH stock was definitely downward throughout the life span of Project Eyeball. However, this was due in large part to the fact that the Singapore stock market index, charted through the performance of 45 key stocks and published in the city-state's largest daily newspaper as the Straits Times Index (STI), began a long slide almost as Project Eyeball was conceived. The STI topped 2,500 briefly at the end of 1999, but as soon as 2000 dawned it began to trend downward, as did other world markets. By the time Project Eyeball hit the streets, the STI was hovering around 2,000. By the time its closure was announced, the stock index had fallen below 1,700. However, as drastic as the fall in share prices in Singapore was in 2000, the drop in SPH stock value was even more pronounced. Table 2 lists a summary of SPH share prices, calculated as a ratio of the STI from the spring of 2000 until the summer of 2001, when Project Eyeball was closed.

The price of SPH stock significantly underperformed the market in Singapore throughout the period, and according to press reports this may have been due in large part to the losses being incurred by Project Eyeball. In the absence of boardroom transparency, managerial strategy can only be inferred, but it is a logical assumption that the poor performance of SPH share prices due to its proliferation of unprofitable ventures may have led to the closure of Project Eyeball.

Table 2. SPH Share Price Versus Straits Times Index

\begin{tabular}{lllr}
\hline Month End & SPH & STI & Ratio \\
\hline April 2000 & 33.4 & 2164 & 1.00 \\
May 2000 & 25.7 & 1795 & .93 \\
June 2000 & 27 & 2037 & .86 \\
July 2000 & 29.5 & 2051 & .93 \\
August 2000 & 27.7 & 2147 & .83 \\
September 2000 & 26.1 & 1997 & .85 \\
October 2000 & 25.1 & 1976 & .82 \\
November 2000 & 27.3 & 1952 & .90 \\
December 2000 & 25.6 & 1926 & .86 \\
January 2001 & 23 & 1991 & .75 \\
February 2001 & 22 & 1947 & .73 \\
March 2000 & 19.8 & 1674 & .76 \\
April 2000 & 20.9 & 1722 & .78 \\
May 2000 & 19.5 & 1657 & .76 \\
June 2001 & 20 & 1726 & .75 \\
July 2001 & 19.3 & 1666 & .75 \\
\hline
\end{tabular}

Note. $\mathrm{SPH}=$ Singapore Press Holdings; $\mathrm{STT}=$ Straits Times Index Data from Straits Times.

\section{Conclusions}

The failure of Project Eyeball was probably not attributable to any one single factor, but instead to a combination of factors. Pricing the newspaper at 80 cents may have attracted enough readers eager for an alternative to the staid Straits Times if two new free alternatives had not been added to the mix. In light of changed circumstances, SPH management's decision to fold Project Eyeball and cut its losses is entirely understandable. Although the increased advertising revenue seen marketwide due to the proliferation of publications starting in 2000 is apparent in the data, albeit tentatively, not much of it seemed to flow to Project Eyeball, likely due to its lack of popularity with readers. Its negative effect on SPH share prices was the final nail in Project Eyeball's coffin. In the end, coming as it did at the onset of both an economic slowdown and an explosion of competing publications, Project Eyeball's rapid demise can probably best be explained in two words: bad timing.

\section{Marc Edge \\ (tmarc@ntu.edu.sg)}

is Assistant Professor in the School of Communication and Information at Nanyang Technological University in Singapore. He is the author of Pacific Press: The Unauthorized Story of Vancouver's Newspaper Monopoly (New Star Books, 2001).

\section{Endnotes}

1. The title was explained as "an amalgam of Streets-where it's distributed, and Treats-because it's free” (Mitton, 2001, p. 8).

2. Project Eyeball started out as a "code name" for the prototype publication, but according to one progress report it proved "so suited to what the team aims to produce that it has been adopted as the product name. ... The word 'project' is apt because it connotes something experimental and on-going" (Khalik, 2000, p. 2).

\section{References}

All the news that fits, they print. (1999, December 3). Asiaweek, p. 13.

Ang, P. H. (2002). Media and the flow of information. In D. Da Cunha (Ed.), Singapore in the new millennium: Challenges facing the city-state (pp. 243-268). Singapore: Institute of Southeast Asian Studies.

Bagdikian, B. (1980). Conglomeration, concentration and the media. Journal of Communication, 30, 59-54. 
Bakker, P. (2002). Reinventing newspapers: Free dailies-Readers and markets. In R. G. Picard (Ed.), Media firms: Structures, operations and performance (pp. 77-86). Mahwah, NJ: Lawrence Erlbaum Associates, Inc.

Banerjee, I., \& Yeo, B. (2003). Internet and democracy in Singapore: A critical appraisal. In I. Banerjee (Ed.), Rhetoric and reality: The Internet challenge for democracy in Asia (pp. 259-287). Singapore: Eastern Universities Press.

Blankenburg, W. B. (1995). Hard times and the news hole. Journalism and Mass Communication Quarterly, 72, 634-641.

Case takes issue with higher news-stand prices of SPH papers. (2004, January 17). Straits Times, p. H2.

Chua, M. H. (2000, June 7). SPH to launch newspaper for the hip and opinionated. Straits Times, p. 1.

Cranberg, G., Bezanson, R., \& Soloski, J. (2001). Taking stock: Journalism and the publicly traded newspaper company. Ames: Iowa State University Press.

Doyle, D. (2002). Understanding media economics. London: Sage.

Drohan, M. (1998, April 20). Black geared for fight. Toronto Globe and Mail, p. B1.

Glover, S. (2003, September 13). The price war is over, and it is time to ask who won. The Spectator (London), p. 32.

Henson B. (2000, August 12). Prepare to be provoked-Project Eyeball is spoiling for a fight. Project Eyeball, p. 1.

Henson, B. (2001, June 29). A last look. Project Eyeball, p. 1.

Khalik, S. (2000, February 6). New SPH paper gets its licence. Straits Times, p. 2.

Lacy, S., \& Ghee-Young, N. (1997). Theory, economics, measurement, and the principle of relative constancy. Journal of Media Economics, 10(3), 3-16.

Lacy, S., \& Simon, T. (1993). The economics and regulation of United States newspapers. Norwood, NJ: Ablex.

Lim (2003, November 13). High hopes. Business Times (Singapore), p. 2.

Loo, D. (2002, December 23). Battle of the free-sheets. The Edge (Singapore), p. 16.

Martin, H. (1998, August). Modeling strategy for mass media: A resource-based approach. Paper presented at the Association for Education in Journalism and Mass Communication Annual Convention, Baltimore, MD.

McCombs, M. (1972). Mass media in the marketplace. Journalism Monographs, 24, 1-102.

Media war and pricing hurt Eyeball. (2001, July 3). Straits Times, p. H7.

Mitton, R. (2001, January 8). A media scuffle to the death. Asiaweek, p. 8.
Olynec, N. (2000, June 6). SPH to start new paper in August as it loses industry monopoly. Bloomberg News.

Ong, C. (2000, June 6). Broadcast licences for SPH, newspaper licence for MediaCorp. Business Times (Singapore), p. 1.

Picard, R. G., \& Brody, J. H. (1997). The newspaper publishing industry. Needham Heights, MA: Allyn \& Bacon.

Preston, P. (2003, July 13). Ten years of price warfare and what have we got? Not an awful lot. The Observer (London), p. 6.

Project Eyeball says goodbye, for now. (2001, June 29). Retrieved December 9, 2002, from http://www.getforme.com/previous 290601_ProjectEyeballSaysGoodbyeForNow.htm

Rajeev, P. (2001, June 28). SPH to suspend operations of Project Eyeball newspaper-Singapore media firm cites market conditions. Asian Wall Street Journal, p. M2.

Sai, M. (2004 , January 14). Singapore press raises its prices. Asian Wall Street Journal, p. M3.

Seow, F. T. (1998). The media enthralled: Singapore revisited. London: Lynne Reiner.

Singapore Media Watch. (2001, June 29). Closing down of Project Eyeball: Letter to Singaporeans for Democracy. Retrieved December 9, 2002, from http://www.sfdonline.org/Link\%20Pages/ Link\%20Folders/01Ds/290601.html

Sivanithy, R. (2001, March 28). SingTel's collapse sends STI reeling below 1,700 points. Business Times (Singapore), p. 8.

Snoddy, R. (1996, December 17). Murdoch says cut-price Times will last forever. Financial Times (London).

SPH's net dropped $8.5 \%$ in first half on losses at units. (2001, March 27). Asian Wall Street Journal, p. M3.

SPH to close Project Eyeball Thursday. (2001, June 27). Reuters News.

S'pore stocks creep higher at close, M\&A rules. (2001, June 28). Reuters News.

Sylvie, G., \& Witherspoon, P. D. (2002). Time, change, and the American newspaper. Mahwah, NJ: Lawrence Erlbaum Associates, Inc.

Teh, H. L. (2000, June 7). Singapore's latest paper to readers-Tell us what you want. Business Times (Singapore), p. 1.

Telling it like it is-What the editors say. (2001, March 24). Straits Times, p. H15.

Underwood, D. (1993). When MBAs rule the newsroom. New York: Columbia University Press.

Webb, S. (2000, August 11). New Singapore paper aims to woo younger, tech-savvy readers. Asian Wall Street Journal, p. 9.

Youths shun politics, involvement. (2000, December 20). Straits Times, p. H2. 